\title{
PENGGUNAAN MEDIA PEMBELAJARAN VIDEO UNTUK MENINGKATKAN AKTIVITAS DAN PRESTASI BELAJAR SISWA PADA MATERI BIOTEKNOLOGI
}

\author{
ASIH WIDIASTUTI \\ MAN Wonogiri, Jawa Tengah \\ e-mail : asihnaurofikriy@gmail.com
}

\begin{abstract}
ABSTRAK
Penelitian ini merupakan penelitian tindakan kelas yang dilaksanakan dalam dua siklus. Tiap siklus terdiri dari perencanaan, pelaksanaan, pengamatan dan refleksi. Subjek penelitian ini adalah siswa kelas XII IPA 1 MAN Wonogiri Tahun Pelajaran 2019/2020 dengan jumlah siswa sebanyak 27 orang yang terbagi dalam jumlah siswa laki-laki sebanyak 6 orang dan perempuan 21 orang. Penelitian ini bertujuan untuk meningkatkan prestasi belajar dengan penggunaan media pembelajaran video pada konsep Bioteknologi. Hasil belajar yang dinilai adalah ranah kognitif dengan mengambil nilai tes dan ranah psikomotor berupa aktivitas siswa yang diukur berdasarkan hasil observasi meliputi kegiatan visual yaitu siswa memperhatikan penjelasan guru, kegiatan berbicara yaitu siswa mengajukan pendapat, berdiskusi, dan atau bertanya, kegiatan menulis yaitu siswa menyelesaikan tugas LKS yang berkaitan dengan video pembelajaran, dan kegiatan yang berkaitan dengan emosi yaitu siswa terlihat senang, antusias dan semangat. Hasil penelitian menunjukkan bahwa terjadi peningkatan prestasi belajar (kognitif) pada konsep materi Bioteknologi dengan penggunaan media pembelajaran video. Hal ini dapat dilihat dari rata-rata nilai siswa pada siklus I sebesar 73,86 dan 80,25 pada siklus II. Pencapaian ketuntasan belajar siswa juga mengalami peningkatan, yaitu $74,1 \%$ pada siklus I dan $92,6 \%$ pada siklus II. Data observasi aktivitas siswa pun menunjukkan peningkatan dengan penggunaan media pembelajaran video, rata-rata aktivitas belajar siswa pada siklus I sebesar 52,5\% dan 70\% pada siklus II.
\end{abstract}

Kata Kunci: Aktifitas Belajar, Prestasi Belajar, Media Pembelajaran Video.

\section{PENDAHULUAN}

Proses pembelajaran merupakan sebuah proses komunikasi antara guru dengan siswa melalui bahasa verbalis sebagai media primer dalam penyampaian materi pelajaran (Sanjaya, 2011 : 2). Namun demikian, tidak berarti proses komunikasi tersebut terjadi selalu melalui bahasa verbal, dibutuhkan juga media lain untuk menyampaikan materi pelajaran agar siswa mudah memahami materi. Kegiatan belajar mengajar di dalam kelas sangat bergantung dengan bagaimana guru menyajikan pembelajaran tersebut kepada siswa. Jika seorang guru hanya berdiri di depan kelas dengan menyampaikan materi secara verbal tanpa dibantu dengan media pembelajaran yang mampu memvisualisasikan apa yang sebenarnya ingin disampaikan, maka sangat dimungkinkan siswa akan merasa bosan dan sulit untuk memahami materi dengan baik.

Ditambah dengan materi-materi biologi banyak yang bersifat abstrak jika berkaitan dengan sistem-sistem fisiologi yang terdapat dalam tubuh manusia, misalnya bagaimana proses kedelai menjadi tempe yang hanya bisa terjadi dengan bantuan jamur, dalam hal ini Rhizopus oryzae. Makhluk renik yang hanya bisa dilihat dengan bantuan mikroskop ini tidak bisa diceritakan secara verbal bagaimana dia bekerja mengubah kedelai menjadi tempe. Contoh lain bagaimana para ahli membuat kloning domba doly yang merupakan hasil kloning organisme pertama di bumi ini, serta dinyatakan berhasil karena menghasilkan organisme yang sama persis dengan induknya (domba yang diambil inti sel dari sel tubuhnya) padahal embrio domba ini dibesarkan dalam rahim domba yang berbeda (domba yang diambil sel telurnya). Bagaimana proses kloning dapat terjadi? Tidak cukup digambarkan secara verbal saja karena semua proses itu melibatkan makhluk renik dan organisasi kehidupan pada individu yang paling kecil yaitu sel bahkan contoh kloning diatas yang diperlukan adalah 
pengambilan DNA sel induk yang notabene DNA adalah bagian dari sel yang terletak di dalam organel nukleus atau inti sel, sedangkan inti sel ada dalam sel, sementara sel adalah bagian dari jaringan, jaringan bagian dari organ, organ bagian dari sistem organ dan barulah terbentuk organisme yang kita lihat sebagai individu ini. Proses pembuatan tempe dan kloning diatas adalah contoh-contoh peristiwa biologi yang dikenal sebagai bioteknologi. Penjelasan secara verbal tidak cukup memahamkan peserta didik untuk mempelajari proses-proses bioteknologi tersebut.

Hal tersebut akan sangat berpengaruh terhadap aktivitas belajar siswa dalam mempelajari biologi yang akhirnya juga akan berdampak pada hasil belajar siswa. Banyaknya materi biologi yang tidak konkrit, tidak bisa diamati langsung akan berdampak pada motivasi mereka untuk mempelajarinya lebih lanjut. Maka dari itu diperlukan media yang tepat untuk membantu menyampaikan informasi-informasi yang tidak dapat terwakilkan dengan bahasa verbal saja sehingga siswa bisa memperoleh gambaran bagaimana proses-proses tersebut terjadi. Media yang bisa mendekatkan peristiwa biologis suatu proses bioteknologi dan anatomis (struktur organ dalam) yang sifatnya abstrak hingga mendekati konkrit. Hal ini senada dengan yang disampaikan dalam buku KTSP (Depdiknas, 2006) bahwa "IPA (Biologi) berhubungan dengan cara mencari tahu tentang alam sehingga bukan hanya kumpulan pengetahuan yang berisi fakta, konsep atau prinsip saja tapi juga suatu proses". Dari sini kita paham akan arti penting media yaitu untuk bisa memberikan gambaran akan suatu proses tersebut

Kegiatan belajar mengajar biologi di kelas XII IPA 1 MAN Wonogiri masih cenderung monoton, penjelasan materi lebih didominasi dengan penjelasan secara verbal dan kurang mengoptimalkan media pembelajaran untuk membantu peserta didik dalam memahami materi- materi biologi. Pada saat ini pemanfaatan media hanya menggunakan buku mata pelajaran dan LKS, dampaknya adalah kurang optimalnya hasil belajar biologi siswa. Hal ini dapat diketahui dari hasil Penilaian Akhir Semester (PAS) di tahun ajaran sebelumnya pada materi yang sama, terdapat siswa yang mendapatkan nilai dibawah Kriteria Ketuntasan Minimum (KKM) yang telah ditetapkan yaitu 65 sebesar 56\%. Artinya hanya sekitar $46 \%$ siswa pada tahun ajaran tersebut yang nilainya memenuhi KKM yang sudah ditentukan, kebanyakan aktivitas siswa didalam kelas masih belum mampu mengikuti pembelajaran dengan baik, hal ini dapat dilihat dari aktivitas siswa yang dilakukan selama proses pembelajaran, seperti mengobrol dan bermain dengan teman sebangku atau bahkan tidur dalam kelas saat pembelajaran.

Melihat kondisi tersebut perlu adanya suatu cara untuk membantu siswa mendapatkan hasil belajar biologi yang optimal. Untuk mencapai nilai KKM yang telah ditetapkan, maka dalam proses pembelajaran guru perlu melakukan inovasi pembelajaran termasuk dalam penggunaan media pembelajaran yang bisa mewujudkan pembelajaran aktif, efektif dan bisa meningkatkan hasil belajar. Menurut Gagne (dalam Arief S Sadiman, 2012 : 20) "Pengelompokkan media ada 7 macam yaitu benda, media audio visual, media cetak, gambar diam, gambar gerak, film bersuara dan mesin belajar". Dari 7 kelompok media tersebut adalah media audio visual. Media pembelajaran berbasis Audio Visual adalah media penyaluran pesan dengan memanfaatkan indera pendengaran dan penglihatan serta dapat diterima secara bersamaan (Michael Ricy Sambora, 2016 : 3). Salah satu bentuk media audio visual adalah video. Menurut Agnew dan Kellerman (1996) dalam Munir (2012: 290) video adalah media digital yang menunjukan susunan atau urutan gambar-gambar dan memberikan ilusi, gambaran serta fantasi pada gambar yang bergerak. Sedangkan menurut Gerlach dan Ely dalam Ibrahim, et.al (dalam Daryanto, 2012 : 8) video mempunyai fungsi fiksatif yaitu kemampuan media ini untuk menangkap, menyimpan dan menampilkan kembali suatu proses/objek, serta fungsi manipulatif yang berkaitan dengan kemampuan media untuk memunculkan kembali proses atau objek tersebut setelah mengalami perubahan (manipulasi), misalnya diubah dulu dengan animasi. Selain itu video memiliki fungsi distributif yaitu kemampuan media video untuk menjangkau banyak audien dari berbagai kalangan dalam 
satu kali proses penyajian sehingga lebih menghemat waktu serta sarana prasarana lain.

Media pembelajaran video cocok digunakan untuk membantu siswa menggambarkan konsep maupun materi dalam pembelajaran Biologi yang sulit dipahami karena tingkat keabstrakannya tinggi tanpa dibantu dengan media pembelajaran. Selain itu fungsi media pembelajaran video dapat menghilangkan verbalisme yang hanya bersifat kata-kata, menjadi bentuk visualisasi sehingga lebih mudah dalam menjelaskan materi pelajaran. Misalnya pada materi Bioteknologi yang dipelajari pada kelas XII IPA semester genap. Dalam pengamatan langsung, rendahnya aktivitas belajar yang diikuti rendahnya ketuntasan minimal belajar mereka (prestasi belajarnya) ini dapat teridentifikasi dari : Kurang aktifnya siswa di dalam proses pembelajaran, siswa hanya bersifat pasif sehingga kurang dalam aktivitas belajarnya, siswa tidak memiliki semangat dalam mendengarkan penjelasan guru, dengan meletakkan kepala di meja, mengobrol dengan teman, mengantuk atau bahkan tertidur, tenaga pendidik yang masih monoton dan kurang inovatif di dalam menyampaikan materi pembelajaran, fasilitas yang tersedia belum bisa di manfaatkan sepenuhya dalam proses pembelajaran, lingkungan belajar yang kurang mendukung, karena kebanyakan orang tua siswa bekerja di luar daerah (boro) sehingga kurang pengawasan dalam belajar. Berdasar teori-teori yang disampaikan para ahli diyakini bahwa media pembelajaran video dapat meningkatkan aktifitas positif siswa dan prestasi belajar khususnya mata pelajaran biologi. Sehingga disinilah peneliti mengambil judul "Penggunaan Media Pembelajaran Video Untuk Meningkatkan Aktivitas Dan Prestasi Belajar Siswa Kelas XII MIPA 1 MAN Wonogiri Pada Materi Bioteknologi”

\section{METODE PENELITIAN}

Jenis penelitian ini adalah Penelitian Tindakan Kelas yang terdiri dari dua siklus dan masing-masing siklus terdiri dari 1) perencanaan tindakan (planning), 2) pelaksanaan tindakan (acting), 3) pengamatan (observating), dan 4) refleksi (reflecting). Menurut pendapat Kemmis dan Carr (dalam M. Syukri, 2008 : 3-5), "penelitian tindakan kelas merupakan suatu bentuk penelitian yang bersifat reflektif yang dilakukan oleh pelaku di dalam masyarakat sosial dan bertujuan untuk memperbaiki".

Penelitian ini dilakukan di Madrasah Aliyah Negeri (MAN) Wonogiri, yang merupakan satu-satunya sekolah Islam dibawah Kementerian Agama berstatus negeri di kabupaten Wonogiri. Sekolah ini beralamat di Jalan R. M. Said Wonogiri, desa Singodutan, Kecamatan Selogiri, Kabupaten Wonogiri dengan kodepos 57652. Sekolah ini memiliki 20 rombongan belajar, yaitu 7 rombel kelas X (3 kelas program IPA, 3 kelas program IPS dan 1 kelas program Keagamaan), 7 rombel kelas XI (3 kelas program IPA, 3 Kelas program IPS dan 1 kelas program keagamaan) dan 6 rombel kelas XII (3 kelas program IPA, 2 kelas program IPS dan 1 kelas program keagamaan). Dengan jumlah guru 36 orang PNS dan 12 orang GTT/PTT, dengan kualifikasi akademik rata-rata S-1 dan ada 4 orang guru dengan kualifikasi akademik S-2.

Sebagai subjek penelitian pada kegiatan ini adalah siswa kelas XII IPA 1 dengan jumlah siswa $=27$ orang, terdiri dari 21 siswa perempuan dan 6 siswa laki-laki. Kelas XII IPA 1 merupakan kelas yang diampu langsung oleh penulis sehingga kegiatan penelitian tidak akan mengganggu kegiatan proses pembelajaran dan sekaligus dapat digunakan sebagai salah satu solusi dalam memecahkan masalah pembelajaran yang dirasakan oleh penulis, dimana aktivitas belajar siswa belum seperti apa yang diharapkan demikian pula prestasi belajarnya. Pengamatan aktivitas belajar siswa dengan cara observasi langsung selama proses pembelajaran, adapun lembar observasi telah disiapkan oleh guru. Sedangkan variabel prestasi belajar siswa dilakukan dengan memberikan tes tertulis kepada subjek penelitian.

Penelitian tindakan kelas ini dapat dikatakan berhasil apabila ada peningkatan aktivitas belajar siswa kearah yang lebih baik dari sisi kualitatif dilihat dari sikap siswa saat KBM dan hasil prestasi belajar siswa setelah diberi perlakuan yang pertama (siklus I) dibanding sebelum diberi perlakuan dan begitu seterusnya hingga di siklus II. Pelaksanaan 
pembelajaran dengan menggunakan media pembelajaran video. Adapun kriterianya ditetapkan sebagai berikut :

1. Sekurang-kurangnya $85 \%$ siswa dapat mencapai batas Kriteria Ketuntasan Minimal (KKM) yang telah ditetapkan yaitu 65

2. Aktifitas belajar siswa menjadi lebih positif artinya lebih semangat, lebih aktif, lebih reaktif terhadap pertanyaan ataupun tugas dari guru, lebih antusias dan lebih suka mengeksplorasi dalam pembelajaran yang dibuktikan dengan hasil observasi yang mencapai prosentase minimal 55\%

3. Ketuntasan perorangan siswa dalam proses pembelajaran apabila nilai tes yang diberikan mencapai $\geq$ KKM yaitu 65

\section{HASIL DAN PEMBAHASAN}

Penelitian tindakan kelas ini dilaksanakan dengan urutan sebagai berikut :

1. Memberikan pretes soal bioteknologi sebagai data awal untuk melakukan tindakan kelas.

2. Melakukan observasi langsung terhadap aktivitas belajar siswa selama proses pembelajaran pada pokok bahasan bioteknologi

3. Melakukan pembelajaran dengan menggunakan media video pada pokok bahasan bioteknologi dengan dua siklus.

4. Memberikan tes setiap siklus pembelajaran berakhir, untuk mengetahui sejauh mana tingkat keberhasilan tindakan kelas yang telah dilaksanakan.

Setelah melaksanakan semua proses tersebut dalam siklus I dan siklus II maka diperoleh hasil dan pembahasan sebagai berikut :

\section{A. HASIL}

\section{Pra Siklus/Sebelum Perlakuan/Keadaan Awal}

Berdasarkan urutan langkah yang peneliti buat dalam PTK ini yaitu melaksanakan pretes untuk mengetahui sejauh mana siswa memahami materi bioteknologi jika belum mendapat perlakuan penelitian dan melakukan observasi terhadap 27 siswa saat terjadi proses pembelajaran maka diperoleh hasil dalam diagram sebagai berikut :

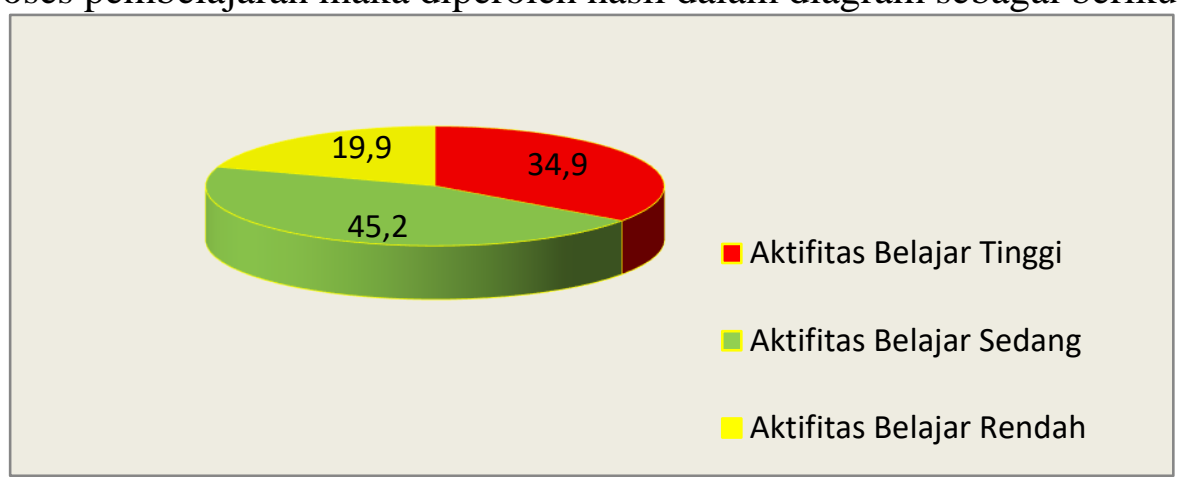

Gambar 1 : Diagram Aktifitas Belajar Siswa sebelum perlakuan / keadaan awal

Setelah diberikan soal pretes kepada siswa, ternyata hanya sebanyak 10 siswa atau 37, 1\% siswa yang dapat mencapai nilai sesuai dengan kriteria ketuntasan minimal $>65$. Hal ini masih jauh dari tujuan yang diharapkan yang harusnya sebesar $85 \%$.

Tabel 1 : Rentang Nilai Pretes

\begin{tabular}{|c|c|c|c|l|}
\hline No & Rentang Nilai & Jumlah & Prosentase & \multicolumn{1}{|c|}{ Keterangan } \\
\hline 1 & $<50$ & 0 & $0 \%$ & Belum tuntas \\
\hline 2 & $51-55$ & 3 & $11,1 \%$ & Belum tuntas \\
\hline 3 & $56-60$ & 6 & $22,2 \%$ & Belum tuntas \\
\hline 4 & $61-65$ & 8 & $29,6 \%$ & Belum tuntas \\
\hline 5 & $66-70$ & 7 & $26 \%$ & Tuntas \\
\hline 6 & $71-75$ & 2 & $7,4 \%$ & Tuntas \\
\hline
\end{tabular}




\begin{tabular}{|c|c|c|c|l|}
\hline 7 & $76-80$ & 0 & $0 \%$ & \\
\hline 8 & $81-85$ & 1 & $3,7 \%$ & Tuntas \\
\hline 9 & $86-90$ & 0 & $0 \%$ & \\
\hline 10 & $91-95$ & 0 & $0 \%$ & \\
\hline 11 & $96-100$ & 0 & $0 \%$ & \\
\hline & Jumlah & 27 & $100 \%$ & $\begin{array}{l}\text { Tuntas }=37,1 \% \\
\text { Belum tuntas }=62,9 \%\end{array}$ \\
\hline
\end{tabular}

Agar lebih jelas hasil pretes diatas digambarkan dalam diagram berikut, yang menunjukkan 10 orang siswa $(37,1 \%)$ dapat mencapai nilai sesuai dengan KKM yang telah ditentukan dan 17 orang $(62,9 \%)$ siswa belum mencapai KKM, dengan nilai rata rata 59,86 .
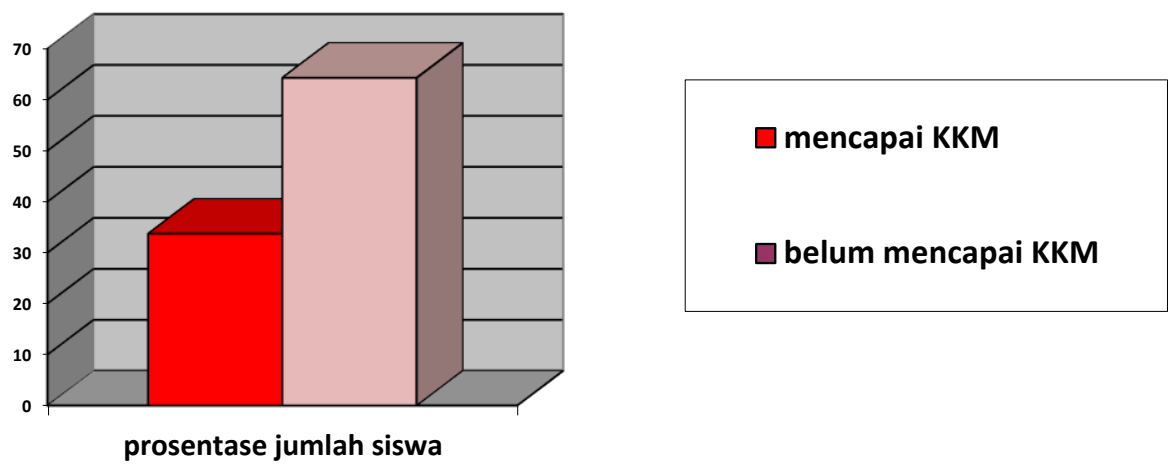

Gambar 2 : Diagram Ketuntasan belajar siswa keadaan awal / sebelum perlakuan

Dari fakta inilah guru berusaha memberikan suatu tindakan atau perlakuan untuk mempermudah pemahaman siswa terhadap kompetensi materi bioteknologi sederhana dan bioteknologi modern menjadi lebih baik, sehingga prestasi belajar mereka juga meningkat dengan pencapaian nilai > 65 sesuai dengan KKM yang telah ditentukan.

\section{Siklus I}

Siklus I adalah pembelajaran materi pokok bioteknologi sederhana dengan menggunakan media model video yang sudah disiapkan/dipilih oleh guru, dengan media ini diharapkan siswa dapat memahami bioteknologi sederhana dengan ciri dan contoh-contoh produknya. Selama proses pembelajaran berlangsung guru melakukan observasi terhadap aktivitas belajar siswa, berdasarkan hasil observasi yang dilakukan oleh guru diperoleh hasil sebagai berikut : yang menunjukkan aktivitas tinggi 48,6\%, aktivitas belajar sedang 42,7\% dan aktivitas belajar rendah 8,7 \%. Agar lebih jelas digambarkan dalam diagram berikut :

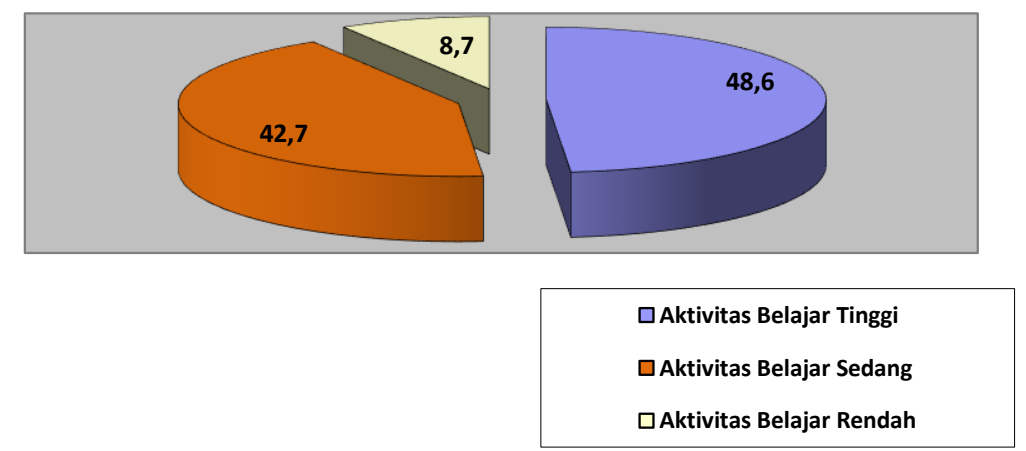

Gambar 3 : Diagram Aktivitas Belajar Siswa pada siklus I 
Adapun rentang nilai yang diperoleh siswa dapat dilihat dalam tabel hasil prestasi belajar yang diperoleh oleh siswa pada siklus I seperti berikut ini :

Tabel 2 : Rentang nilai siswa pada siklus I

\begin{tabular}{|c|c|c|c|l|}
\hline No & Rentang Nilai & Jumlah & Prosentase & \multicolumn{1}{|c|}{ Keterangan } \\
\hline 1 & $<50$ & 0 & $0 \%$ & Belum tuntas \\
\hline 2 & $51-55$ & 1 & $3,7 \%$ & Belum tuntas \\
\hline 3 & $56-60$ & 3 & $11,1 \%$ & Belum tuntas \\
\hline 4 & $61-65$ & 3 & $11,1 \%$ & Belum tuntas \\
\hline 5 & $66-70$ & 11 & $40,8 \%$ & Tuntas \\
\hline 6 & $71-75$ & 4 & $14,8 \%$ & Tuntas \\
\hline 7 & $76-80$ & 1 & $3,7 \%$ & Tuntas \\
\hline 8 & $81-85$ & 2 & $7,4 \%$ & Tuntas \\
\hline 9 & $86-90$ & 2 & $7,4 \%$ & Tuntas \\
\hline 10 & $91-95$ & 0 & & \\
\hline 11 & $96-100$ & 0 & & \\
\hline & Jumlah & 27 & $100 \%$ & Tuntas $=74,1 \%$ \\
& & & & Belum tuntas $=25,9 \%$ \\
\hline
\end{tabular}

Dari tabel di atas dapat dibaca bahwa pada siklus I siswa yang belum tuntas adalah 7 siswa $(25,9 \%)$ dan yang telah tuntas 20 siswa $(74,1 \%)$ dengan rata-rata nilai 73,86, hal ini berarti secara klasikal pembelajaran di siklus I ini juga belum tuntas karena ketuntasan klasikal dinyatakan telah tercapai jika siswa yang memperoleh nilai diatas KKM yang telah ditetapkan adalah sebesar $\geq 85 \%$. Adapun hasil yang diperoleh adalah 20 siswa $(74,1 \%)$ telah dapat mencapai KKM dan 7 siswa $(25,9 \%)$ belum mencapai KKM, agar lebih jelas dapat dilihat pada diagram berikut :

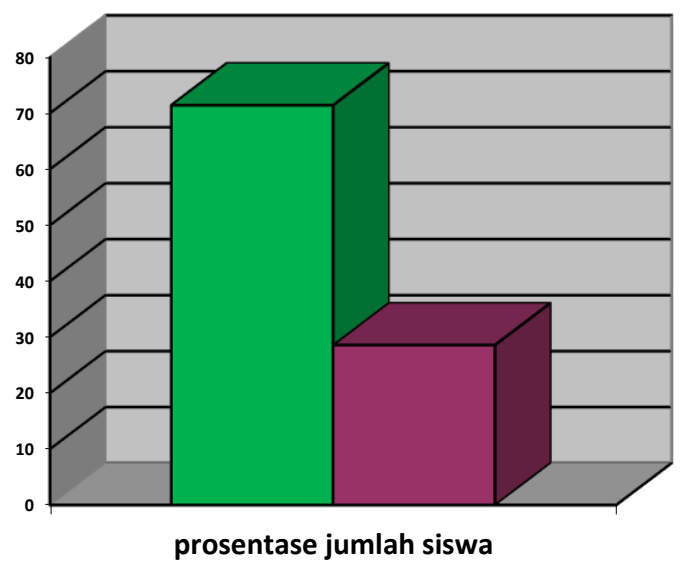

$\square$ mencapai KKM

$\square$ belum mencapai KKM

Gambar 4 : Diagram Ketuntasan belajar pada siklus I

\section{Siklus II}

Selama proses pembelajaran materi pokok bioteknologi siswa telah menggunakan media video, sehingga keterlibatan dan keaktifan siswa dalam mengikuti proses pembelajaran lebih meningkat, dan hal ini berpengaruh pula terhadap peningkatan aktivitas belajar siswa selama mengikuti pembelajaran. Disamping itu guru membahas soal-soal yang salah dikerjakan oleh siswa pada latihan sebelumnya dan siswa diberi kesempatan lagi untuk mengerjakan soal-soal latihan yang baru agar pemahaman mereka terhadap materi pelajaran lebih bermakna dan tidak mudah lupa. 
Saat proses pembelajaran berlangsung guru melakukan observasi terhadap aktivitas belajar siswa, berdasarkan hasil observasi yang dilakukan oleh guru diperoleh hasil sebagai berikut : yang menunjukkan aktivitas tinggi 82,6\%, aktivitas sedang $17,4 \%$ dan aktivitas rendah $0 \%$. Agar lebih jelas digambarkan dalam diagram berikut:
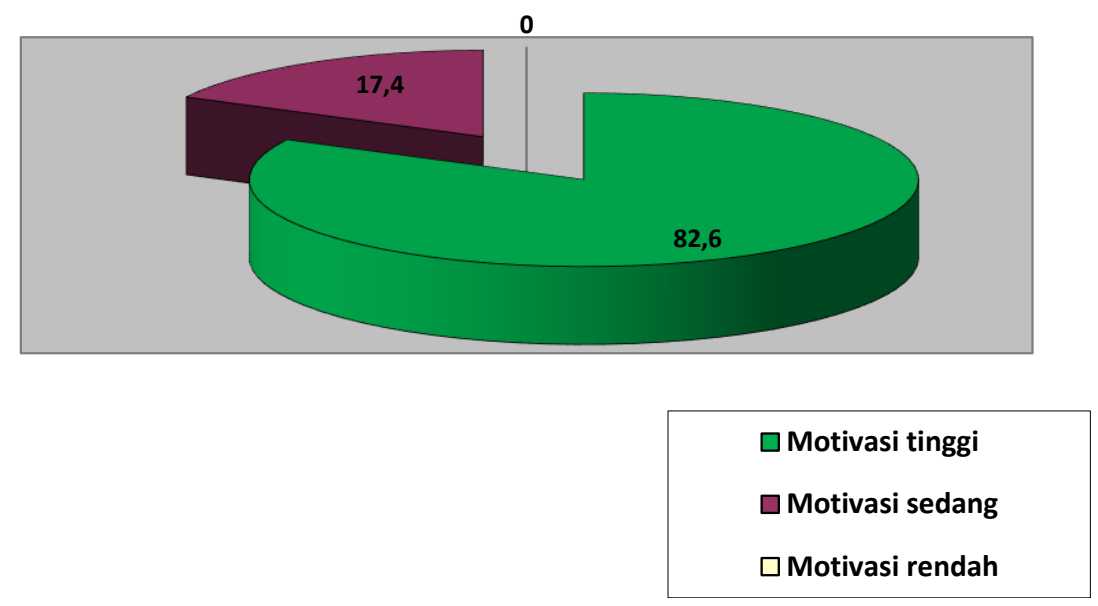

Gambar 5 : Diagram Aktivitas belajar siswa pada siklus II

Adapun rentang nilai yang diperoleh siswa dapat dilihat dalam tabel hasil prestasi belajar yang diperoleh oleh siswa pada siklus II seperti berikut ini :

Tabel 3 : Rentang nilai siswa pada siklus II

\begin{tabular}{|c|c|c|c|l|}
\hline No & Rentang Nilai & Jumlah & Prosentase & \multicolumn{1}{|c|}{ Keterangan } \\
\hline 1 & $<60$ & 0 & $0 \%$ & Belum tuntas \\
\hline 2 & $61-65$ & 2 & $7,4 \%$ & Belum tuntas \\
\hline 3 & $66-70$ & 5 & $18,5 \%$ & Tuntas \\
\hline 4 & $71-75$ & 7 & $25,9 \%$ & Tuntas \\
\hline 5 & $76-80$ & 5 & $18,5 \%$ & Tuntas \\
\hline 6 & $81-85$ & 3 & $11,1 \%$ & Tuntas \\
\hline 7 & $86-90$ & 3 & $11,1 \%$ & Tuntas \\
\hline 8 & $91-95$ & 1 & $3,7 \%$ & Tuntas \\
\hline 9 & $96-100$ & 1 & $3,7 \%$ & Tuntas \\
\hline & Jumlah & 27 & $100 \%$ & Tuntas $=92,6 \%$ \\
& & & & Belum tuntas $=7,4 \%$ \\
\hline
\end{tabular}

Dari tabel di atas dapat dibaca bahwa pada siklus II siswa yang belum tuntas adalah 2 siswa $(7,4 \%)$ dan yang telah tuntas 25 siswa $(92,6 \%)$ dengan rata-rata nilai 80,25 , hal ini berarti secara klasikal telah tuntas karena ketuntasan klasikal telah tercapai jika siswa yang dapat memperoleh nilai $\geq$ KKM yang telah ditetapkan $\geq 85 \%$. Adapun hasil yang diperoleh adalah sebagai berikut 25 siswa $(92,6 \%)$ telah dapat mencapai KKM dan 2 siswa $(7,4 \%)$ belum mencapai KKM, agar lebih jelas dapat dilihat pada diagram berikut : 


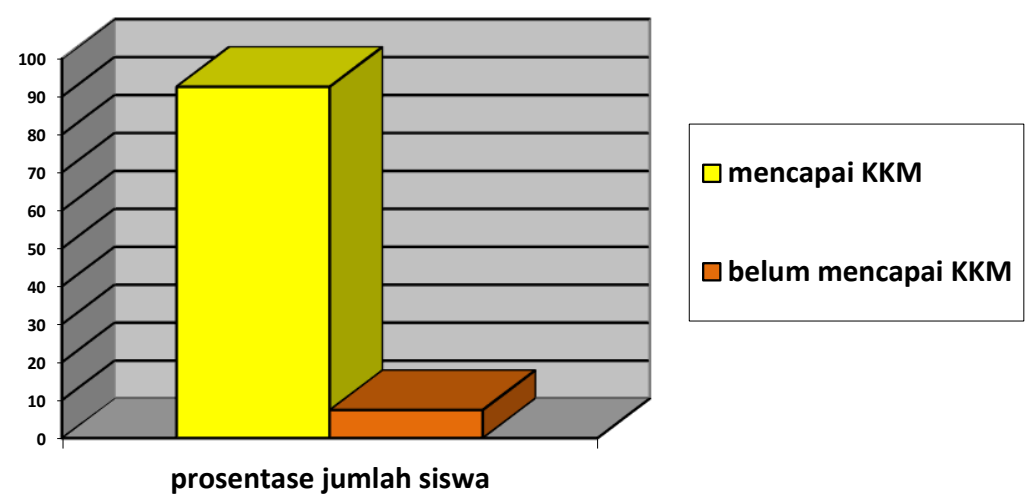

Gambar 6. Diagram Ketuntasan belajar pada siklus II

\section{B. PEMBAHASAN}

Dari hasil yang diperoleh dalam siklus I, dimana aktifitas belajar siswa sudah ada peningkatan kearah yang positif dari saat sebelum mendapat perlakuan dimana guru menggunakan metode ceramah, yang dampaknya siswa tidak antusias dalam pembelajaran, banyak siswa meletakkan kepala di meja, saling mengobrol antar mereka bahkan ada yang mengerjakan tugas/pekerjaan rumah mata pelajaran lainnya. Setelah peneliti menggunakan media pembelajaran berupa video di siklus I hasilnya terjadi peningkatan aktivitas belajar kearah positif dimana aktivitas belajar siswa kategori tinggi adalah jika siswa yang menunjukkan sikap positif dan proaktif selama proses pembelajaran berlangsung, aktivitas belajar sedang jika sikap siswa positif tetapi kurang proaktif selama proses pembelajaran berlangsung, aktivitas belajar siswa rendah jika siswa kurang menunjukkan sikap positif dan kurang proaktif selama proses pembelajaran berlangsung. Dari perlakuan di siklus I aktivitas belajar siswa sudah ada kemajuan dari pra siklus dimana terdapat selisih kearah yang lebih baik sebagai berikut :

aktivitas belajar tinggi ada peningkatan $13,7 \%$

aktivitas belajar sedang $2,5 \%$

aktivitas belajar rendah $67,1 \%$.

Kenaikan signifikan terjadi pada aktivitas belajar dari yang tingkat rendah, artinya dengan media pembelajaran video siswa sudah merasa tertarik atau lebih positif dalam aktivitas belajarnya, namun dari sisi prestasi belajar yang merupakan hasil siswa dalam mengerjakan tes belum memuaskan. Hal ini di siklus refleksi dianalisis karena hal-hal berikut ini :

1) Dilihat dari sisi guru :

1.1 Walaupun sudah menggunakan media Video, cara guru menyampaikan materi kepada peserta masih kurang menarik.

1.2 Guru kurang efisien dalam memanfaatkan ketersediaan waktu.

1.3 Guru masih kurang tegas dalam mengendalikan peserta didik di dalam kelas

1.4 Video yang dipilih masih yang dua dimensi jadi hanya berisi gambar berjalan, sehingga guru masih juga harus banyak menjelaskan dengan kata-kata, masih ada unsur ceramah yang lumayan banyak

2) Dilihat dari sisi siswa :

1.1 Beberapa peserta didik tidak memperhatikan penyampaian materi oleh guru dengan tertib.

1.2 Pada pelaksanaan pembelajaran menggunaan video banyak yang masih bercanda dan terkesan gaduh selama proses berlangsung.

1.3 Beberapa peserta didik terlambat masuk kelas karena pergantian jam dari istirahat ke jam berikutnya (biologi) 
Dalam teori yang disampaikan oleh Rusman dkk (2012 : 172) dikatakan bahwa media pembelajaran video dapat meningkatkan aktivitas belajar siswa. Menyakini teori tersebut dan diperkuat hasil penelitian sebelumnya yang dilakukan oleh Michael Ricy Sambora bahwa penggunaan media Audio Visual bentuk Video dapat meningkatkan hasil belajar kognitif siswa kelas X IPS 2 SMA BATIK 1 Surakarta tahun pelajaran 2015/2016 serta masih ditemukannya beberapa kekurangan dalam siklus I maka peneliti melanjutkan ke siklus II. Hasil refleksi di siklus II menunjukkan hasil yang lebih baik dan kenaikannya siginifikan. Hal ini antara lain karena media video yang dilihat siswa dibuat guru 3 dimensi, sehingga video bergerak bahkan sampai proses pembuatan produk-produk bioteknologinya dibuat dengan cara dipraktikkan langsung dalam video tersebut, berbeda dengan saat siklus 1 video yang dibuat materi video powerpoint saja sehingga kurang menarik dan menggairahkan siswa untuk memperhatikan tayangan videonya. Disamping itu adanya waktu khusus yang digunakan oleh guru untuk membahas kesalahan yang masih sering dilakukan oleh siswa di siklus sebelumnya, sehingga siswa memperoleh kesempatan untuk memperbaiki kesalahannya dalam mengerjakan tugas dan soal. Juga adanya waktu yang disediakan oleh guru, dimana siswa diberi kesempatan lagi untuk berlatih soal setelah kesalahan dibetulkan oleh guru, sehingga pembelajaran menjadi lebih bermakna. Hal inilah yang lebih memotivasi siswa sehingga siswa dapat meraih hasil belajar tinggi sesuai dengan tujuan yang diharapkan. Hasil ini senada dengan yang diperoleh dalam penelitian tindakan kelas yang dilakukan oleh Oriza Sipayung dalam jurnalnya menyatakan bahwa "penerapan metode pemanfaatan video sebagai media pembelajaran dapat meningkatkan hasil belajar menggambar teknik dasar siswa kelas X program keahlian konstruksi batu dan beton SMK N 2 Pematangsiantar”.

Adapun dari awal timbulnya masalah pembelajaran biologi pada pokok bahasan bioteknologi yang dialami oleh siswa kelas XII IPA 1 MAN Wonogiri tahun pelajaran 2019/2020, sampai dengan dicari solusi untuk menguraikan masalah tersebut melalui penelitian tindakan kelas dengan menggunakan media pembelajaran video, diperoleh hasil sebagai berikut :

Tabel 4 : Perubahan keadaan awal dan akhir, meliputi nilai rata-rata dan ketuntasan belajar

\begin{tabular}{|c|l|c|c|c|}
\hline \multicolumn{2}{|c|}{ Hal yang diungkap } & Keadaan awal & Siklus I & Siklus II \\
\hline \multirow{2}{*}{\begin{tabular}{c} 
Aktivitas $\begin{array}{c}\text { Belajar } \\
\text { Siswa }\end{array}$ \\
\cline { 2 - 5 }
\end{tabular}} & Tinggi & $34,9 \%$ & $65,2 \%$ & $82,6 \%$ \\
\hline & Redang & $51,3 \%$ & $31,7 \%$ & $17,4 \%$ \\
\hline $\begin{array}{l}\text { Nilai rata- } \\
\text { rata }\end{array}$ & & $13,8 \%$ & $3,1 \%$ & $0 \%$ \\
\hline $\begin{array}{l}\text { Ketuntasan } \\
\text { belajar }\end{array}$ & $\begin{array}{l}59,86 \\
73,86\end{array}$ & 80,25 \\
\cline { 2 - 5 } & $\begin{array}{l}\text { Tuntas } \\
\text { tuntas }\end{array}$ & $35,71 \%$ & $71,43 \%$ & $92,6 \%$ \\
\hline Keterangan & $\begin{array}{l}\text { Belum mencapai } \\
\text { ketuntasan } \\
\text { klasikal }\end{array}$ & $\begin{array}{l}\text { Belum } \\
\text { mencapai } \\
\text { ketuntasan } \\
\text { klasikal }\end{array}$ & $\begin{array}{l}\text { Sudah } \\
\text { mencapai } \\
\text { ketuntasan } \\
\text { klasikal }\end{array}$ \\
\hline
\end{tabular}

Dari indikator keberhasilan penelitian yang dibuat dan melihat tabel hasil penelitian tindakan kelas maka (1) Sekurang-kurangnya 85\% siswa dapat mencapai batas Kriteria Ketuntasan Minimal (KKM) yang telah ditetapkan yaitu 65, (2) aktifitas belajar siswa menjadi lebih positif artinya lebih semangat, lebih aktif, lebih reaktif terhadap pertanyaan ataupun tugas dari guru, lebih antusias dan lebih suka mengeksplorasi dalam pembelajaran yang dibuktikan dengan hasil observasi yang mencapai prosentase minimal 55\%, (3) ketuntasan perorangan siswa dalam proses pembelajaran apabila nilai tes yang diberikan mencapai $\geq \mathrm{KKM}$ yaitu 65 . Hasil ini 
diperkuat dengan hasil penelitian serupa yang dilakukan oleh Bayuda Luqman AlFarisi \& Nengsih Juanengsih yang menyatakan dalam kesimpulannya berdasarkan pembahasan dan data-data yang telah diuraikan disimpulkan bahwa media pembelajaran video dapat meningkatkan hasil belajar siswa pada konsep sistem reproduksi manusia.

\section{KESIMPULAN}

Kesimpulan yang peneliti peroleh dari penelitian ini dengan melihat hasil dan pembahasan yang diperoleh maka dapat ditarik kesimpulan sebagai berikut :

1. Penggunaan media video dapat menarik minat siswa, sehingga siswa lebih antusias dalam mengikuti proses pembelajaran yang artinya aktivitas belajar siswa tinggi

2. Penggunaan media video dapat membantu siswa untuk mengkonstruksi pembelajaran yang bersifat abstrak menjadi lebih kongkrit sehingga mudah dipahami oleh siswa yang berakibat siswa tidak mudah melupakan materi pelajaran.

3. Motivasi adalah kunci keberhasilan dalam belajar, sehingga jika siswa memiliki motivasi yang tinggi dalam proses pembelajaran, maka siswa akan lebih memiliki aktivitas tinggi dalam belajar yang diikuti dengan memperoleh prestasi belajar yang tinggi pula

4. Penggunaan media pembelajarn video dapat dikembangkan lebih lanjut dengan video yang lebih inovatif

\section{DAFTAR PUSTAKA}

Arif S. Sadiman. 2007. Media Pembelajaran, Pengertian, Pengembangan dan Pemanfaatannya. Jakarta : PT. Raja Grafindo Perkasa

Bayuda Luqman Al-Farisi \& Nengsih Juanengsih. 2014. Penggunaan Media Pembelajaran

Video Untuk Meningkatkan Hasil Belajar Biologi Siswa Pada Konsep Sistem Reproduksi Manusia. e-mail: yudha_alfarisi@yahoo.com

Carr W \& Kemmis S. (2008). Becoming critical: Education, knowledge and action research. London: The Falmer Press

Daryanto. (2012) Penelitian Tindakan Kelas dan Penelitian Tindakan Sekolah. Yogyakarta : Grava Media

Micahel Ricy Sambora. (2016). Penggunaan Media Audio Visual Bentuk Video Untuk Meningkatkan Hasil Belajar Siswa Pada Mata Pelajaran Sosiologi X Ips 2 Sma Batik 1 Surakarta Tahun Pelajaran 2015/2016,12-13.

Munir. 2012. Multimedia Konsep dan Aplikasi Dalam Pendidikan. Bandung : Alfabeta

Oriza Sipayung \& Darwin. 2016. Jurnal Education Building. Volume 2, Nomor 1, Juni 2016 : 87-93 ISSN : 2477-4898

Rusman dkk. 2012. Model-Model Pembelajaran. Jakarta : Raja Grafindo Persada

Wina Sanjaya. 2011. Perencanaan dan Desain Sistem Pembelajaran. Jakarta : Kencana

$$
\text { Nasional. }
$$

2006. Kurikulum KTSP 2006. BSNP : Departemen Pendidikan 